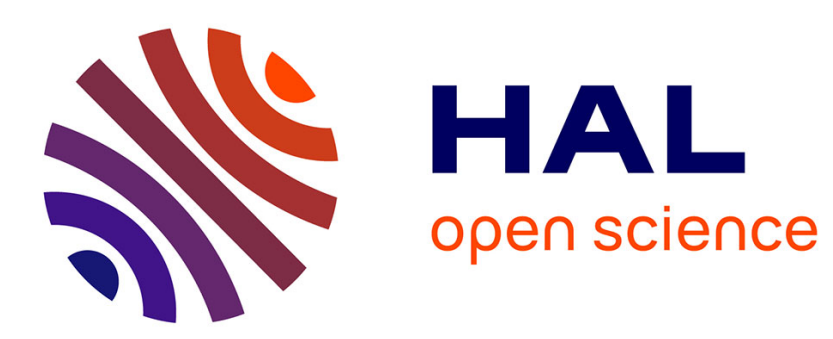

\title{
Cross-tolerance to abiotic stresses in halophytes: Application for phytoremediation of organic pollutants
}

Moez Shiri, Mokded Rabhi, Abdelhak El Amrani, Chedly Abdelly

\section{To cite this version:}

Moez Shiri, Mokded Rabhi, Abdelhak El Amrani, Chedly Abdelly. Cross-tolerance to abiotic stresses in halophytes: Application for phytoremediation of organic pollutants. Acta Physiologiae Plantarum, 2015, 37 (10), pp.209. 10.1007/s11738-015-1954-0 . hal-01153749

HAL Id: hal-01153749

https://hal-univ-rennes1.archives-ouvertes.fr/hal-01153749

Submitted on 30 Oct 2015

HAL is a multi-disciplinary open access archive for the deposit and dissemination of scientific research documents, whether they are published or not. The documents may come from teaching and research institutions in France or abroad, or from public or private research centers.
L'archive ouverte pluridisciplinaire HAL, est destinée au dépôt et à la diffusion de documents scientifiques de niveau recherche, publiés ou non, émanant des établissements d'enseignement et de recherche français ou étrangers, des laboratoires publics ou privés. 


\section{Authors' names:}

Moez Shiri ${ }^{\mathrm{a}, \mathrm{b}}$, Mokded Rabhi ${ }^{\mathrm{b}}$, Abdelhak El Amrani ${ }^{\mathrm{a}}$, and Chedly Abdelly

Title: Cross-tolerance to abiotic stresses in halophytes: application for phytoremediation of organic pollutants

\section{Authors' affiliations:}

a: CNRS, Université de Rennes 1, UMR 6553, Ecosystèmes-Biodiversité-Evolution, 35042 Rennes cedex, France.

b: Laboratory of Extremophile Plants, Centre of Biotechnology of Borj Cedria, P.O. Box 901, 2050 HammamLif, Tunisia.

*Corresponding author: Dr. Mokded Rabhi

E-mail: $\underline{\text { mokded.rabhi@gmail.com }}$

Phone number: + 21679325848

Fax number: + 21679325638

\section{Author Contributions Statement}

Moez Shiri prepared the manuscript and Mokded Rabhi, Abdelhak El Amrani, and Chedly Abdelly discussed and revised it. 


\begin{abstract}
Halopytes are plants able to tolerate high salt concentrations but no clear definition was retained for them. In literature, there are more studies that showed salt-enhanced tolerance to other abiotic stresses compared to investigations that found enhanced salt tolerance by other abiotic stresses in halophytes. The phenomenon by which a plant resistance to a stress induces resistance to another is referred to as cross-tolerance. In this work, we reviewed cross-tolerance in halophytes at the physiological, biochemical, and molecular levels. A special attention was accorded to the cross-tolerance between salinity and organic pollutants that could allow halophytes a higher potential of xenobiotic phytoremediation in comparison with glycophytes.
\end{abstract}

Keywords: genomic level, metabolomic level, physiological level, proteomic level, transcriptomic level. 


\section{Introduction}

Halophytes are plants known for their ability to tolerate high salt levels in the soil. However, no clear definition was given to them and researchers still cannot certainly distinguish between halophytes and glycophytes. Flowers and Colmer (2008) call a halophyte any plant able to complete its seed-to-seed cycle at $200 \mathrm{mM} \mathrm{NaCl}$ or higher. Halophytes are considered to be rare plant species that arose separately in unrelated plant families during the diversification of Angiosperms (O’Leary and Glenn 1994; Flowers et al. 2010) similarly to epiphytes, saprophytes, xerophytes, aquatics, and marsh plants (Kremer and Van Andel 1995). They were estimated to constitute 1 to $2 \%$ of the flora (Flowers and Colmer 2008). Several fundamental and applied (economical) potential uses were attributed to halophytes as promising phytoresource. At the fundamental level, they help understand mechanisms involved in high salinity tolerance using morphological, anatomical, ultrastructural, physiological, biochemical, and molecular tools (Jithesh et al. 2006; Barhoumi et al. 2008; Smaoui et al. 2010; Rabhi et al. 2010b; Ellouzi et al. 2011; Debez et al. 2013; Ben Hamed et al. 2014). At the applied level, halophytes are used for food, fodder, forage, edible oil, biofuel, medicines, phytoremediation, phytodesalination, sandy soil fixation, ornamentation... (Khan and Qaiser 2006; Rabhi et al. 2010a, Rabhi et al. 2010d, Zaier et al. 2010; Al-Oudat and Qadir 2011).

Among several classifications of halophytes, a habitat-based one distinguishes between xerohalophytes, those thriving under saline arid conditions, and hydrohalophytes, those thriving under saline moist conditions (Al-Oudat and Qadir 2011). In their natural habitats, halophytes are simultaneously subjected to a multitude of abiotic stresses. However, data about pretreatment of halophytes with abiotic stresses such as draught, heavy metals, flooding, and nutrient deficiencies to enhance their tolerance to salinity are scarce. Recently, Ellouzi et al. (2013) investigated the responses of the halophyte Cakile maritima to increasing salt concentrations after pretreatment with three abiotic stresses: drought, salinity, and cadmium. They found that all pretreatments enhanced salt tolerance in this species through oxidative stress alleviation, in particular under severe salinity conditions. A seed priming with a relatively high $\mathrm{CaCl}_{2}$ concentration $(50 \mathrm{mM})$ was also shown to alleviate the adverse effects of high $\mathrm{KCl}, \mathrm{NaCl}, \mathrm{Na}_{2} \mathrm{SO}_{4}$, and $\mathrm{MgSO}_{4}$ concentrations on germination of Urochondra setulosa (Shaikh et al. 2007).

In literature, there are more works about salt-enhanced tolerance to other abiotic stresses than about enhanced salt tolerance by other abiotic stresses in halophytes (See Ben Hamed et al. 2013). In Artemisia anethifolia and Suaeda salsa, salt adaptation enhanced PSII tolerance to heat stress through an improvement of 
thermotolerance of PSII reaction centers, oxygen-evolving complexes, and light-harvesting complex (Lu et al. 2003). In Hordeum maritimum, it was also shown that moderate salinity alleviated the effects of phosphorus deficiency (Talbi-Zribi et al. 2012). Moreover, under low potassium availability conditions, salt stress improved $\mathrm{K} / \mathrm{Na}$ selectivity in this halophyte (Hafsi et al. 2007). In the same context, Glenn et al. (2012) showed that salinity enhances Atriplex spp. tolerance to drought in drying soils. Beneficial salt effects on Sesuvium portulacastrum responses to drought (Slama et al. 2007) and heavy metals (Ghnaya et al. 2005; Zaier et al. 2010) were also reported. Salt priming was also shown to improve Distichlis spicata establishment under low to moderate salinity conditions (Sargeant et al. 2006).

Cross-tolerance is defined as the phenomenon by which a plant resistance to a stress induces resistance to another (Genoud and Metraux 1999). Because much of the injuries they induce in plants are associated with oxidative damage at the cellular level, oxidative stress tolerance is thought to play a key role in cross-tolerance to a variety of environmental stresses (Iseki et al. 2013).

\section{Mechanisms involved in halophyte salt-induced tolerance are common to other abiotic stresses}

\subsection{Cross-tolerance physiology}

\subsubsection{Intracellular compartmentalization of toxic molecules and osmotic adjustment}

As subjected to salt stress, halophytes compartmentalize excess ions predominantly in vacuoles, maintaining in this way their concentrations in the cytoplasm within tolerable limits. They accumulate organic osmolytes such as proline, glycinebetaine, and sugars mainly in cytoplasm for osmotic adjustment without impairing metabolic activities (Debez et al. 2010). This significantly contributes to the overall water relations that allow halophytes to obtain water from saline soils (Flowers and Colmer 2008). Osmolyte accumulation under salt-induced water deficiency was also observed in the case of direct (insufficiently-irrigated soil) and PEG- and mannitol-induced drought (Slama et al. 2007; Rouached et al. 2013). The comparison between Hordeum martimum and H. vulgare after $60 \mathrm{~h}$ of salt stress showed that the former is more able to accumulate inorganic solutes (such as $\mathrm{Na}^{+}$) in vacuoles for osmotic adjustment and to keep organic solutes and a large part of $\mathrm{K}^{+}$for metabolic activities. Such an economic strategy was absent in $H$. vulgare whose osmotic adjustment was based on organic osmolytes regardless of stress severity (Yousfi et al. 2010). Munns (2002) reported that the use of one mole of $\mathrm{Na}^{+}$, mannitol, proline, glycinebetaine, or sucrose as an osmoticum in leaf cell needs $3.5,34,41,50$, or 52 moles of ATP, respectively. Moreover, even within halophytes themselves, species differ in succulence and in the solutes they accumulate, Chenopodiaceae being more able to use salt ions in osmotic adjustment than Poaceae (Flowers 
and Colmer 2008). Succulence results in an increase in cell size and a decrease in growth extension, this process reduces surface area per tissue volume, leading to higher water content per unit area (Weber 2008).

Maintaining water status within plant tissues requires, in addition to osmotic adjustment, a decrease in water losses through a decline in stomatal conductance $(g s)$. Nevertheless, differences between halophytes were described. For instance, in a comparative study between two obligate halophytes Sesuvium portulacastrum $\left(\mathrm{C}_{3}\right)$ and Tecticornia indica $\left(\mathrm{C}_{4}\right)$, different stomata responses were observed at moderate salt concentration $(200 \mathrm{mM}$ $\mathrm{NaCl}$ ); in the former $g s$ was enhanced whereas in the latter it showed no variation. At higher salt concentration (400 $\mathrm{mM} \mathrm{NaCl}$ ), this parameter was decreased in both species. The decrease in $g s$ constitutes an identical early response to water and salt stress (Munns 2002). Indeed, plant responses to salt stress occur in two phases: a fast osmotic phase (whose period depends on species and stress severity) due to the increase in external osmotic pressure followed by a slower ionic phase due to ion accumulation in leaves (Munns and Tester 2008). Water use efficiency $\left(W U E=A / E\right.$ with $A$ and $E$ standing respectively for net $\mathrm{CO}_{2}$ assimilation and transpiration rate) was shown to be a good tool for measuring the aptitude of a plant to adjust its gas exchanges under stressful conditions by increasing $\mathrm{CO}_{2}$ capture and reducing water losses (Gleick et al. 2011).

Vacuole sequestration is not limited to salt ions but it is also extended to a variety of toxic ions and molecules such as heavy metals (Hossain et al. 2012) and organic pollutants (Tissut et al. 2006). In the case of heavy metals, a prior chelation phase is needed (Mendoza-Cózatl et al. 2010). As regards organic pollutants, three phases are often described: 1) biotransformation that converts xenobiotics into more polar compounds (in some cases, this phase is not necessary), 2) conjugation that adds to the xenobiotics sugars, amino acids, or peptides to facilitate their metabolism, and 3) sequestration of conjugated molecules into vacuoles or their fixation to the cell wall components (Tissut et al. 2006).

\subsubsection{Excretion of toxic molecules}

Many halophytes were shown to have trichomes or salt glands controlling salt accumulation in plant tissues. Salt glands are embedded in the leaf epidermis. They can be multicellular, as observed in Dicots (Plumbaginaceae and Tamaricaceae), or bicellular, as reported in Monocots (Poaceae; Barhoumi et al. 2008). Trichomes are composed of two parts: $i$ ) a stalk embedded in the epidermis bearing ii) a unicellular bladder cell with a huge vacuole, a well-reduced cytoplasm pushed close to the wall, and only a few organelles (Smaoui et al. 2010). In some cases, salt excretion is performed by leaf cuticle as described in Suaeda fruticosa (Chenopodiaceae), a species with no excreting glands or trichomes (Labidi et al. 2010). Hence, salt excretion is a phenomenon by which halophytes eliminate excess salt reaching their leaves (Sobrado 2002) in a highly-selective way, secreting 
mostly $\mathrm{NaCl}$ and thus contributing to maintain a suitable $\mathrm{K}^{+} / \mathrm{Na}^{+}$ratio of cell cytoplasm. However, other ions such as $\mathrm{K}^{+}, \mathrm{Mg}^{2+}, \mathrm{Ca}^{2+}$, and $\mathrm{SO}_{4}{ }^{2-}$ can be excreted (Sobrado and Greaves 2000) if they are in excess in leaf tissues. Manousaki and Kalogerakis (2011) reported also that salt glands and trichomes on leaf surfaces of some halophytes (such as Tamarix smyrnensis, Atriplex halimus, Armeria maritime, Avicennia marina, Avicennia germinans, and Spartina alterniflora) can excrete excess metals as a possible detoxification mechanism.

\subsubsection{Nutrient homeostasis}

Nutrient homeostasis is one of the major factors allowing halophytes to survive under extreme saline conditions. It is based on two main strategies: nutrient uptake efficiency and nutrient use efficiency. Since the most abundant salt is $\mathrm{NaCl}$, the former strategy relies on cation $/ \mathrm{Na}^{+}$selectivity and anion $/ \mathrm{Cl}^{-}$one that increase to mitigate the salt-induced reduction in nutrient uptake efficiency (Hafsi et al. 2007; Rabhi et al. 2010c). However, $\mathrm{K}^{+} / \mathrm{Na}^{+}$ selectivity is the most studied one as this macronutrient is often more affected by salinity than other nutrients. Although nutrient/salt selectivity is often described in halophytes in response to salt stress, it is not sufficient to maintain nutrient uptake efficiency at the level of the control. This is why high use efficiency is needed (Hafsi et al. 2007; Rabhi et al. 2010c). Mineral nutrition is imbalanced by several stresses other than salinity. For instance, the two halophytic Aeluropus species A. lagopoides and A. littoralis displayed an increase in $\mathrm{K}^{+}$and $\mathrm{Na}^{+}$ concentrations under drought stress (Vaziri et al. 2011). This is important for osmotic adjustment during water stress as inorganic osmolytes increase osmotic potential. Gulzar et al. (2003) who observed an enhancement in $\mathrm{K}^{+}$level in A. lagopoides tissues attributed such a response to drought stress to a high selectivity for $\mathrm{K}^{+}$by retaining higher $\mathrm{Cl}^{-}$and $\mathrm{Mg}^{2+}$ ions in roots. Heavy metal stress is also a factor of nutrition disturbances and plants able to maintain their nutrient homeostasis under this stress are thought to overcome it. For instance, the two halophytes Sesuvium portulacastrum and Mesembryanthemum crystallinum experienced different potassium and calcium status as subjected to a range of cadmium $(\mathrm{Cd})$ concentrations $(0,50,100,200$, and $300 \mu \mathrm{M})$, the former being more able to maintain its nutrient homeostasis than the latter (Ghnaya et al. 2007). This was due to the fact that $S$. portulacastrum displayed a higher aptitude to produce biomass and to limit Cd uptake even under severe stress conditions than M. crystallynum (Ghnaya et al. 2007), which is probably due to its higher $\mathrm{Ca}^{2+}$ and $\mathrm{K}^{+}$selectivity over $\mathrm{Cd}^{2+}$. In addition, recently, Zhan et al. (2013) found that a $\mathrm{K}^{+}$influx/ $\mathrm{H}^{+}$efflux reaction is coupled with the transport of the Polycyclic Aromatic Hydrocarbon (PAH) phenanthrene into root cells, which constitutes a new insight into its uptake by plant roots. This also opens new perspectives on the role of nutrient homeostasis in plant tolerance to organic pollutants, in particular in halophytes. 


\subsubsection{Membrane integrity}

Plant cells contain many membrane systems that are not considered as simple barriers delimiting different compartments; they are specialized to particular functions undertaken by their lipid components and membraneassociated proteins (Komatsu et al. 2007). Hence, almost all plant responses to environmental stresses directly or indirectly require membrane integrity to be maintained, although stresses themselves cause significant intracellular restructuring (Buchanan et al. 2000). The most studied membranes under abiotic stress conditions are plasmalemma, tonoplast, and thylakoid membranes. Plasmalemma plays structural and communicating (interface with the extracellular environment exchanging information and substances) roles. Hence, it constitutes the site of signal processing in response to stresses (Komatsu et al. 2007). To estimate membrane integrity under stress, some usual parameters are often used: i) malondialdehyde (MDA) concentration that constitutes an indirect measurement of lipid peroxidation (for all membranes), ii) electrolyte leakage that indicates the degree of the plasmalemma permeability and therefore its inaptitude to retain electrolytes (for plasmalemma since it is the last membrane to be crossed, iii) the correlation between excessive salts within a tissue and its water content to estimate the degree of their sequestration into vacuoles (for tonoplast), and $i v$ ) chloroplast ultrastructure that illustrates the degree of damage in grana (for thylakoid membranes). In halophytes, as in all plants, the use of these parameters among others have shown that a variety of severe abiotic stresses induce membrane damages (Ben Hassine et al. 2009; Parida and Jha 2013), which is due to the generation of Reactive Oxygen Species (ROS) responsible for oxidative stress (Bose et al. 2013). Hence, ROS homeostasis is one of the major factors allowing halophytes higher salt tolerance in comparison with glycophytes (Bose et al. 2013).

ROS overproduction was described in halophyte responses to several abiotic stresses as reviewed by Jithesh et al. (2006). It is initiated by the univalent reduction of $\mathrm{O}_{2}$ or the transfer of excess excitation energy to $\mathrm{O}_{2}$. The transfer of one, two, or three electrons generates respectively superoxide radicals $\left(\mathrm{O}_{2}{ }^{--}\right)$, hydrogen peroxide $\left(\mathrm{H}_{2} \mathrm{O}_{2}\right)$, or hydroxyl radical (HO) (Mittler 2002). Nevertheless, plants are equipped with two antioxidant systems that can scavenge ROS and therefore protect cell membranes and molecules from damages. The non-enzymatic system groups a variety of molecules such as tocopherol, carotenoids, ascorbate, and glutathione, whereas the enzymatic one groups several enzymes, namely superoxide dismutase, catalase, ascorbate peroxidase, monohydroascorbate reductase, dehydroascorbate reductase, and glutathione reductase (Jithesh et al. 2006).

Chloroplast (thylakoid membrane) is one of the main targets of ROS. Its protection is therefore a priority in halophytes under stress conditions. Rabhi et al. (2010b) showed that the halophyte Sesuvium 
portulacastrum is able to protect thylakoid membranes and proteins even at $400 \mathrm{mM} \mathrm{NaCl}$. Similar results were also found in the halophyte Sulla carnosa under magnesium deficiency conditions (Farhat et al. 2014, 2015) as well as under individual and combined effects of salinity and iron deficiency (Unpublished data).

2.2. Biochemical and molecular mechanisms of cross-tolerance

\subsubsection{Gene duplication and promoter adaptation}

Gene duplication is a kind of genome adaptive mechanisms to environment fluctuations (Kondrashov 2012). The identification of copy-number variations (CNVs) in response to stressful or changing conditions may help understand gene duplications as an adaptive mechanism. Studies of 80 Arabidopsis thaliana ecotypes showed that natural selection has led to CNVs covering 2.2 Mb of the reference genome (Cao et al. 2011). The genomes of A. thaliana and its halophyte relative Thellungiella parvula have approximately $10 \%$ of their total genes in tandem duplicates (Dassanayake et al. 2011), and they are clearly involved in the species dramatically different stress tolerance strategies. This is exemplified by the amplification of $N H X 8$ homologs, known to encode a putative $\mathrm{Li}^{+}$transporter in A. thaliana (An et al. 2007). The duplication led to a constitutively higher expression in T. parvula than in A. thaliana. This was probably responsible for the improvement of T. parvula tolerance to high $\mathrm{Li}^{+}$concentrations in its natural biotope. Some other examples were also reported such as the duplications of $C B L 10$ orthologs, encoding a calcium sensor, $A V P 1$, encoding a vacuolar proton transporter in T. parvula, and $H K T$, present in a single copy in A. thalina and in three ones in T. parvula (Dassanayake et al. 2011).

Based on molecular and genomic studies, several key transcription factors were identified to be induced under several abiotic stress conditions. Among them, DREB and ABF are well characterized transcription factors known to play an important role in regulating gene expression in response to abiotic stresses through both ABAindependent and dependent pathways. In parallel, many salt-induced promoters are not specific to salinity. Promoters of the stress-induced genes contain cis-regulatory elements such as DRE/CRT, ABRE, MYC recognition sequence (MYCRS), and MYB recognition sequence (MYBRS), which are regulated by various upstream transcriptional factors (Mahajan et al. 2005; Zhu 2002). Nawaz et al. (2014) compared expression levels and promoter activities of candidate salt tolerance genes in the halophyte $T$. salsuginea and the glycophyte A. thaliana using promoter swap experiments. They showed that SOS1 and VATD promoters were respectively five-fold and two-fold more active in $T$. salsuginea than in A. thaliana. These observations were supported by an expression of a higher number of gene families nonspecific to salt stress in the halophyte than in the glycophyte (Wu et al. 2012). 


\subsubsection{Wide genome transcriptional adaptation to abiotic stresses}

Wu et al. 2012 found that 21 transcription factor families were expanded in $T$. salsuginea genome as compared to that of A. thaliana. These expansions may be associated with the adaptation of $T$. salsuginea to extreme environments, as individual members of some A. thaliana factor families have been shown to be related to stress tolerance. For example, the RAV gene family that has been reported to respond to several stresses, including salinity (Fowler et al. 2005; Sohn et al. 2006), expanded from six members to nine, respectively in A. thaliana and T. salsuginea (Wu et al. 2012). In the extreme halophyte Salicornia brachiata, transcript profiling revealed an abundance of SbUSP (an uncharacterized universal stress protein gene) transcripts in response to salt stress as well as to drought, heat, and cold stresses. Heterologous expression of this gene conferred salt and osmotic tolerance to E. coli (Udawat et al. 2013). Some other salt-responsive genes cloned from this halophyte experienced also elevated expression under abiotic stress conditions in the host plant. For instance, $S b$ MT-2 gene was up-regulated by salinity, drought, and heat stresses and its expression increased with treatment time (Chaturvedi et al. 2012). The peroxisomal ascorbate peroxidase gene ( $\operatorname{pbAPX}$ ) was also strongly induced by cold (Singh et al. 2013). In addition, pAPX gene cloned from Avicenia marina was up-regulated by salinity, $\mathrm{H}_{2} \mathrm{O}_{2}$, prolonged light, and ferric citrate treatment (Kavitha et al. 2008). In the same context, a SUMO conjugating (Small Ubiquitin related Modifier) enzyme gene 'SaSce9' from experienced induced transcripts under salinity, drought, cold, and exogenously supplied ABA conditions in leaves as well as in roots of the halophytic grass Spartina alterniflora. Its constitutive overexpression in A. thaliana improved its tolerance to salinity and drought (Karan and Subudhi 2012). In the halophyte Limoniastrum monopetalum, El-Bakatoushi (2011) showed that crude oil exposure over-expressed salt and drought genes.

2.2.3. Proteomic analysis revealed the induction of several non specific-stress- and defense-related proteins

While addressing the key pathways regulating abiotic stress plant adaptation, comprehensive data presented confirmed that proteins are relevant tools to confer tolerance. Therefore, it has been found out that salinity induces more proteomic changes in A. thaliana than in T. salsuginea (Oliver et al. 2011; Gechev et al. 2012; Dooki et al. 2006). The former displayed 88 differentially abundant protein spots versus 37 ones in T. salsuginea as compared to their controls (Dooki et al. 2006). Therefore, salinity changes more the proteomic profile of $A$. thaliana as compared to that of $T$. salsuginea since the latter is able to maintain enough photosynthetic activity and ATP production for stress adjustment. A proteomic study of Suaeda salsa under individual and combined 
effects of salinity and heat shock showed that out of 80 proteins whose levels were increased by salt stress and 70 proteins whose levels were reduced by heat shock, an overlap of only 17 proteins was detected. In addition, out of 112 proteins accumulated by the combined effects, only 43 were salt-elevated and 30 were heat shockelevated (Li et al. 2011). Hence, among 124 induced proteins (during salinity, heat shock, or their combination), only 14 were common in the three treatments ( $\mathrm{Li}$ et al. 2011). Interestingly, the authors found an overexpression of STO5 not only by salt stress but also by heat shock and their combination, which can lead to higher salt tolerance in transgenic plants (Nagaoka and Takano 2003). An aluminum-induced protein-like protein (AIPLP) that has been shown to be involved not only in aluminum stress response but also in other metal, wounding (Snowden et al. 1995), and drought stress responses (Oztürk et al. 2002), was induced in Puccinellia tenuiflora under $95 \mathrm{mM} \mathrm{Na}_{2} \mathrm{CO}_{3}$ treatment, which suggests that it might also contribute to its tolerance to $\mathrm{Na}_{2} \mathrm{CO}_{3}$ stress (Yu et al. 2013). In addition, a developmentally-regulated plasma membrane polypeptide (DREPPPM)-like protein that has been shown to be involved in cold acclimation and salt stress, increased under $\mathrm{Na}_{2} \mathrm{CO}_{3}$ stress. This protein may be associated with the $\mathrm{Ca}^{2+}$ signal transduction pathway in the seedlings of Puccinellia tenuiflora under $\mathrm{Na}_{2} \mathrm{CO}_{3}$ stress (Yu et al. 2013).

\subsubsection{Cross-tolerance-enhanced abundance of protective proteins involved in photosynthesis activation and protein biosynthesis}

Abiotic stresses negatively affect photosynthesis at different levels, altering both photochemichal and nonphotochemical processes (Saibo et al. 2009). Nevertheless, plants have developed many adaptive strategies allowing them to cope with severe conditions (Zhu 2002; Saibo et al. 2009). Identification of photosynthesisrelated proteins that are differentially abundant under drought and severe salt stress is very important. So far, many photosynthesis-related proteins exhibited an increase or decrease in response to these two stresses (Oliver et al. 2011; Vanhove et al. 2012; Aranjuelo et al. 2011). The comparison between halophyte and glycophyte proteins under salt stress reviewed by Kosová et al. (2013) reported an increase in PsbP, ferredoxin-NADPH reductase, OEE2, RubisCO activase, TPI, GAPDH, and Glucose-6-P dehydrogenase in glycophytes and an increase in LHC, OEE2, RubisCO LSU and SSU, RubisCO activase, D2, CP24, CP47, PSI subunit IV, carbonic anhydrase; SBP, and PGK. In response to salinity, non-salt-specific proteins can be accumulated. For instance, Chen et al. (2012) found an enhanced abundance in eleven heat-shock proteins (HSPs) in the halophyte Nitraria sphaerocarpa under saline conditions. Based on literature and their own results, the authors suggested an HSP/chaperone network in plants that responds to salinity. As subjected to salt stress, the halophytic plant 
Puccinellia tenuiflora exhibited an increased abundance of tocopherol cyclase, a crucial enzyme in the biosynthesis of $\alpha$-tocopherol in plants (Yu et al. 2011) conferring it higher stress tolerance. It is also known that free metal ions can catalyze ROS formation. Therefore, responses leading to the elimination of free metal ions were observed in salt-stressed plants (Kosová et al. 2013). Stress also results in an accumulation of several protective proteins as chaperones from HSP90 family, HSP70 family, and Hsc70 (heat-shock cognate) (Kosová et al. 2013). Other stress-protective proteins, such as osmotin and osmotin-like proteins, are involved in enhancing osmotic stress responses. PR-10 proteins respond not only to biotic, but also to abiotic stresses, such as drought, salt, cold, and oxidative stresses, and UV-irradiation (Agarwal et al. 2013).

\subsubsection{Abiotic-stress-commonly-induced alterations in carbohydrate nutritional status}

Sugar metabolism is a very dynamic process and its metabolic fluxes and concentrations highly fluctuate with development stage and in response to environmental stresses (Rolland et al. 2006). Under abiotic stress, glucose has an important role as osmolytes in maintaining cell turgor, stabilizing cell membranes, and decreasing protein degradation (Sharp et al. 2004). Non-reducing disaccharides such as trehalose can accumulate with higher levels in tolerant plants. Other sugars with no energetic role, such as the oligosaccharides raffinose and stachyose were accumulated in response to abiotic stress conditions such as drought, salinity, and ex treme temperatures (Kaplan et al. 2004). Relevant physiological studies have shown that soluble carbohydrates, like glucose, fructose, sucrose, or fructans, significantly contribute to the mechanisms of adaptation to salt stress (Parida et al. 2002). Gil et al. (2011) studied sugar accumulation in five halophytes (Juncus acutus, Juncus maritimus, Plantago crassifolia, Inula crithmoides, and Sarcocornia fruticosa) and found that sucrose, and at a lower level, glucose and fructose were the most abundant sugars in J. acutus and J. maritimus, and sorbitol the only soluble sugar accumulated in P. crassifolia. In addition to their involvement in osmotic adjustment, soluble carbohydrates stabilize also proteins and membrane structure and protect plant cell against ROS, especially in halophyte species (Szabados and Savouré 2010; Boriboonkaset et al. 2013). Polyols and sugar alcohols like mannitol or sorbitol were also accumulated and linked to abiotic stress tolerance (Arbona et al. 2008). In addition to all cited roles, sucrose, fructose, and glucose play also pivotal roles as signaling molecules to abiotic stresses (Koch, 2004; Rolland et al. 2006; Ruan 2014).

\subsubsection{Enhanced biosynthesis of organic osmolytes, phenolic compounds, and lignin}

Under abiotic stresses, plants synthesize osmolytes like soluble sugars and amino acids that contribute to turgor maintaining by osmotic adjustment (Arbona et al. 2003; Arbona et al. 2008). In this context, it is interesting to 
follow the synthesis and levels of osmolytes involved in stress tolerance such as amino acids, secondary metabolites, and regulatory metabolites (Arbona et al. 2013). Indeed, increases in Proline (Pro) content have been reported in response to a variety of abiotic stress conditions like salt stress (Yoshiba et al. 1995; Arbona et al. 2008), soil flooding (De Campos et al. 2011), drought (Arbona et al. 2008), and extreme temperatures (Kaplan et al. 2004). The target enzyme is a pyrroline-5-caboxylate synthetase (P5CS) (Arbona et al. 2008). Pro plays also a role in ROS scavenging (Arbona et al. 2003) as well as in DNA, membrane, and protein stabilization (Arbona et al. 2008). Polyamines (PA) also have protective ROS scavenging roles (Alet et al. 2012). A variety of abiotic stresses were shown to induce PA accumulation that was found to positively correlate with stress tolerance (Martin-Tanguy 1997; Bitrián et al. 2012). Putrescine (Put), spermidine (Spd), and spermine (Spm) are the most abundant PAs found in higher plants (Arbona et al. 2013). It has been recently reported that, in nonadapted Thellungiella salsuginea accessions, sugars and polyamines could be involved in the mechanisms of cold adaptation (Colinet et al. 2012). However, the most described and important compounds are sugars, sugar alcohols, and nitrogenous compounds with low molecular weight (in particular Pro and glycinebetaine). Their accumulation in adapted plants is thought to be involved in their tolerance to stresses (Witt et al. 2012). Under heavy metal stress, to reduce metal accumulation in photosynthetic organs is considered as a tolerance trait like phytochelatin biosynthesis and glutathione metabolism (Arbona et al. 2013).

It is known that heat induces PAL activity and phenolic production and reduces, at the same time, their oxidation, contributing to heat stress acclimation (Arbona et al. 2013). The precursors of lignins, phenylpropanoids are also involved in stress defense mechanisms, in particular in roots where they can adjust cell wall composition and stiffness (Van Poecke et al. 2001; D’Auria et al. 2005).

Carotenoids and xanthophylls are lipophilic compounds synthesized in plants from isopentenyl pyrophosphate (IPP) via the plastidial methyl erythritol phosphate (MEP) pathway. The role of carotenoids is not restricted to cell protection from UV radiation under stress conditions. Indeed, it was demonstrated that the overexpression of phytoene synthase gene in transgenic tobacco plants resulted in a higher osmotic and salt tolerance, but through channeling carotenoid flux to ABA biosynthesis which resulted in an enhancement of ABA levels (Cidade et al. 2012).

The following diagram (Figure) summarizes specific and non-specific responses to combined stresses.

Figure. Schematic diagram showing the possible cross-talk involved in the response of halophytes to multiple stresses. The signal pathways resulting from several stresses induce specific and non-specific genes that can 
confer stress-tolerance. The latter are responsible for cross-tolerance. GPCR: G-protein-coupled receptor; RLK: receptor-like kinase; CBL: calcineurin B-like interacting protein kinase; CPK: calcium-dependent protein kinase; MAPK: mitogen-activated protein kinase; ROS: reactive oxygen species; TFs: transcription factors.

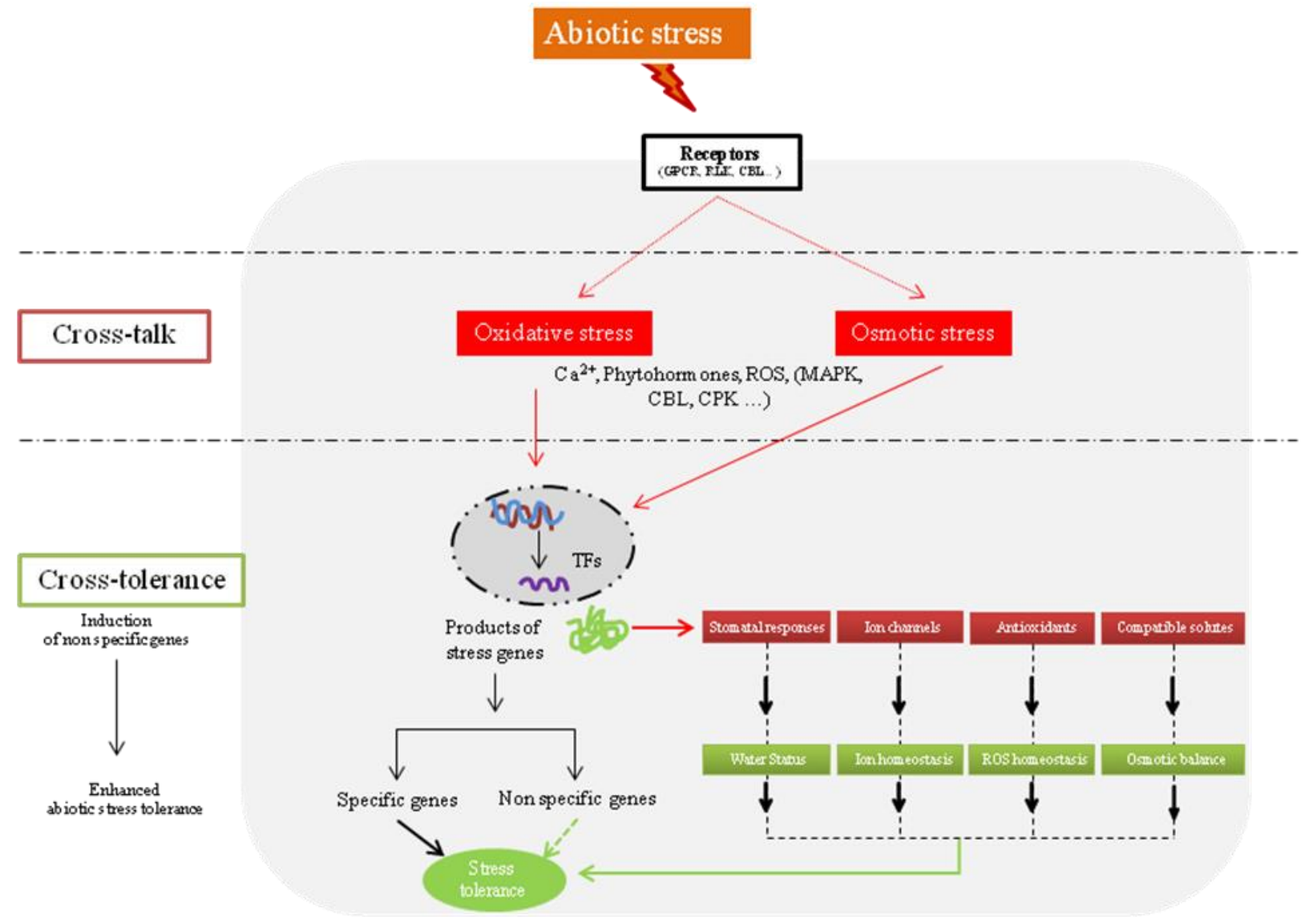




\section{Cross-tolerance between salinity and organic pollutants: application for phytoremediation}

3.1. Compartmentalization and subcellular sequestration are common mechanisms involved in salinity and organic pollutant tolerance

As heavy metals and salts, organic pollutants constitute one of the major hazardous chemicals that contaminate soils today (El-Bakatoushi 2011). The uptake of toxic organics in plant cells and/or their sequestration or metabolism are essential for detoxification of the rhizosphere and in turn for phytoremediation. Therefore, organic pollutants such phenanthrene may passively penetrate the plasmalemma of root and shoot cells (Alkio et al. 2005). Wild et al. (2004) traced the movement of anthracene in maize leaves and showed that it was localized on the leaf surface; it diffused into the cytoplasm within $72 \mathrm{~h}$. This finding was supported by Alkio et al. (2005) who showed that phenanthrene can diffuse in Arabidopsis through direct contact with the tissue as well as from the air. Also, Zhan et al. (2010) found in wheat two modes of phenanthrene transport; a simple diffusion and an active absorption by a transporter. In the same context, Cobbett and Meagher (2002) reported that the uptake of organic xenobiotics into the plant cell is often mediated by an $\mathrm{ABC}$ transport protein. A subclass of the $\mathrm{ABC}$ transporters, originally named the multi drug resistance proteins (MRPs) in reference to animal cells and bacteria, is the best-characterized family of plant proteins that carry organics across membranes. MRPs are involved in the uptake, efflux, and sequestration of toxic compounds and xenobiotics (Tommasini et al. 1998). In literature, little is known about the mechanisms of Polycyclic Aromatic Hydrocarbon (PAH) metabolism and accumulation in plants. All authors used the green lever model to explain plant cell internalization, degradation, and sequestration of organic compounds such as PAHs (Sandermann 1992). In plants, the metabolism of xenobiotics can be divided into three phases leading to the neutralization of the organic pollutant: transformation (Phase I), conjugation (Phase II), and compartmentalization (Phase III) (Sandermann 1992). The first two phases are similar to those used by animals. During phase I, the compound is transformed by oxidation (frequently), reduction, or hydrolysis, creating one or more functional groups on the molecule (Komives and Güllner 2005). The hydrophobic character of organic pollutants like PAHs suggests hydroxylation by specific enzymes to transform them into hydro-soluble compounds in cytoplasm. Hence, in phase II, one or more substituents are attached onto endogenous or existing active sites formed during Phase I. The main reactions include conjugation of glycosides, glutathione, amino acid, or malonic acid. During phase III, the soluble compounds are either stored in the vacuole or incorporated into lignin or other cell wall components of becoming non-extractable. Due to its similarity with the hepatic detoxification mechanisms in animals, the term "green liver" has been adopted for the operation of plant cells during xenobiotic metabolism (Sandermann 1994). This concept was supported 
by Alkio et al. (2005) who demonstrated that in A. thaliana, phenanthrene was detected and sequestrated in particular cell "trichomes" and after higher amount of PAHs it was diffused to basal unclear cells, with increased the levels of particular mono- or dioxygenases that allow increased tolerance and transform PAHs to non-toxic intermediate compounds during phase I (Cerniglia 1997; Kanaly and Harayama 2000).

Similarly, since monovalent ions, used by halophytes and salt-tolerant glycophytes for osmotic adjustment, are toxic at the required concentrations, $\mathrm{Na}^{+}$and $\mathrm{Cl}^{-}$are predominantly vaculole-compartmentalized to maintain their concentrations in the cytoplasm within tolerable limits (Whyn Jones and Gorham 2002). Although the evidence is limited, $\mathrm{Na}^{+} / \mathrm{H}^{+}$exchange and the activity of one or more of the PMF-generating enzymes appear to play a role in the accumulation of $\mathrm{Na}^{+}$as they increase under saline conditions. However, ion transport across tonoplast is not sufficient for efficient compartmentalization; their retention within vacuoles is also required and was shown to be correlated with low tonoplast fluidity (Leach et al. 1990). Hence, one can speculate that since halophytes are more efficient in saline ion compartmentalization than glycophytes, they are theoretically more able to sequester any other toxic ion or compound.

3.2. ROS accumulation and signaling are common features shared between stresses induced by salinity and organic pollutants

Liu et al. (2009) suggested that phenanthrene oxidized by mono- or di-oxygenases, like the CYP, increased ROS level, which induces oxidative stress. However, it cannot be confirmed if oxidative stress is a consequence of phenanthrene detoxification activities or of its own or derivative phytotoxicity (Liu et al. 2009). ROS production is an unavoidable event for all organisms exposed to oxygen and $\mathrm{Na}^{+}$and $\mathrm{Cl}^{-}$accumulation in the cytosol increased ROS production (Allakhverdiev et al. 2002). The result of hydroxylation of organic pollutant by cytochrome P450 generated also ROS production. A higher antioxidant capacity in halophytes than in glycophytes has been suggested to confer them a higher tolerance to stresses such as salinity (Flowers and Colmer 2008; Kosová et al. 2013) and phenanthrene toxicity (Shiri et al. 2014). Mittler (2006) reported that the exposure of a plant to a combination of several abiotic stresses will co-activate different stress-response pathways. The results of stress combination have a synergistic or antagonistic effect. This suggests that a crosstalk between co-activated pathways is likely to be mediated at different levels. These could involve a variety of transcription factor networks, mitogen-activated protein kinases (MAPK) (Cardinale et al. 2002; Xiong and Yang 2003), a multitude of stress hormones (ethylene, jasmonic acid, and abscisic acid) (Anderson et al. 2004), 
calcium and/or ROS signaling (Mittler et al. 2004; Bowler and Fluhr, 2000) as well as numerous receptors and signaling complexes (Casal 2002).

The stress tolerance by increasing antioxidant activity is attractive to explain a high tolerance in halophytes to organic pollutants that generated an oxidative stress (Liu et al. 2009). Therefore, the higher levels of enzymatic antioxidants in halophytes, in particular that of SOD, suggest that the crucial role to rapid conversion of $\mathrm{O}_{2}{ }^{-}$to $\mathrm{H}_{2} \mathrm{O}_{2}$ may be essential for early defense signaling. Halophyte species induced rapidly $\mathrm{H}_{2} \mathrm{O}_{2}$ levels, then they have higher SOD level 'in stock' (Bose et al. 2011). Secondly, high levels of APX and CAT may interfere with $\mathrm{H}_{2} \mathrm{O}_{2}$ signaling and decrease its positive role. However, only $\mathrm{OH}$ is highly reactive and causes significant damage to cell structures and is the major compound resulting from hydroxylation of PAHs, it is also known to activate directly a range of $\mathrm{Na}^{+}, \mathrm{K}^{+}$, and $\mathrm{Ca}^{2+}$-permeable cation channels (Demidchik et al. 2010; Zepeda-Jazo et al. 2011) disturbing $\mathrm{K}^{+} / \mathrm{Na}^{+}$ratio within cytoplasm and inducing programmed cell death (PCD) (Shabala et al. 2007; Shabala, 2009; Demidchik et al. 2010).

3.3. The understanding of salinity and organic pollutant tolerance may help improve phytoremediation Phytoremediation is known as a green technology using plants to remediate contaminated-environments. It is cheap, non-instructive, and effective means of pollutant cleanup. In literature, little is known about halophyte use in phytoremediation of organic pollutants. The majority of the examples of phytoremediation by halophytes was reported in salt marshes, their natural habitats (Howes Keiffer and Ungar 2002; Al-Mailem et al. 2010; Masciandaro et al. 2014; Ribeiro et al. 2014). Salt marshes constitute important ecosystems severely exposed to risks due to the oil spills resulting from accidental discharges, leakage from boats, industrial wastewater discharges, and urban runoff (Ribeiro et al. 2014). Phytoremediation of organic pollutants is based on the observation that planted contaminated soil versus unplanted soil showed on acceleration of organic pollutant degradation in the presence of plants (Burken and Schonoor 1996; Masciandaro et al. 2014). There are two different strategies of phytoremediation: direct and explanta phytoremediation (Salt et al. 1998). The first one consists of pollutant uptake by analogy to phytoextraction of heavy metals. However, the availability of organic pollutants depends on their physicochemical properties and their concentration in soil (Wenzel et al. 1999). The second one is based on exudates synthesized by roots like enzymes involved in the degradation of organic pollutants and other compounds stimulating fungi and bacteria growth that use pollutants as carbon source.

In this context, phytoremediation of organic pollutants remains unexplored enough. The majority of investigations in this field focused on the interaction between microorganisms and roots to improve the 
degradation of organic pollutants in soil. Some studies reported that PAHs can be taken up by plant leaves from air or by their roots from soil (Simonich and Hites 1994; Kipopoulou et al. 1999; Fismes et al. 2002). Indeed, because of their high lipophily, they are adsorbed either on leaf cuticle and passed through it by solubilization in waxes or on root suberine cortical zones and absorbed by root cells (Simonich and Hites 1994; Kipopoulou et al. 1999; Fismes et al. 2002). The halophyte Halocnemum strobilaceum naturally inhabiting hypersaline soils was shown to remediate soil contaminated by aromatic hydrocarbon in the Arabian Gulf (Al-Mailem et al. 2010). A 'phytoremediation' culture of Cakile maritima on sterilized sand (without microorganisms) contaminated with phenanthrene significantly decreased its phytotoxicity in a subsequent culture of Thellungiella salsuginea (Shiri et al. 2015). Meudec et al. (2005) investigated also the uptake of fuel oil PAHs by the halophytic plant Salicornia fragilis and the bioaccumulation of these compounds into shoot tissues in the upper aerial part of the plant. This finding proves that plants are able to take up and to accumulate PAHs in their biomass. This bioaccumulation depends on the time and dose of exposure to fuel oil in the sediment. In this example of halophytic plant, the uptake by roots of PAHs seems to be the main pathway. The particular morphology of Salicornia plants (no real leaf) and the absence of PAHs in control also suggest that PAHs detected are not originated from atmospheric contamination. The different PAH distribution suggests that low molecular weight PAHs, like phenanthrene and pyrene due to their higher solubility, are transported more easily in the phloem than high molecular weight PAHs like benzo(a)pyrene. Fismes et al. (2002) reported that the transport of low molecular weight PAHs from root to aerial parts could be passive and driven by transpiration flux.

\section{Concluding remarks}

Halophytes are of significant interest since they naturally occur in environments with excess toxic ions and research findings suggest that they also tolerate other abiotic stresses through cross-tolerance mechanisms that allow them tolerance to several stresses in addition to salt stress tolerance. In this review, we focused on crosstolerance mechanisms in halophytes at the physiological, genomic, transcriptomic, proteomic, and metabolomic levels with an emphasis on their cross-tolerance to salinity and organic pollutants. Their powerful subcellular sequestration of toxic ions and compounds and their high activities of antioxidant enzymes constitute key traits in their high tolerance to both salinity and organic pollutant stresses. However, data about halophyte use in the phytoremediation of organic pollutant-contaminated soils are scarce. Comparative studies between halophyte and glycophyte responses to these pollutants are encouraged. In addition, the effects of optimal salinity levels on halophyte phytoremediation potential of organic pollutants are particularly required. 


\section{References}

Agarwal P, Garg V, Gautam T, Pillai B, Kanoria S, Burma PK (2013) A study on the influence of different promoter and 5'UTR (URM) cassettes from Arabidopsis thaliana on the expression level of the reporter gene $\beta$ glucuronidase in tobacco and cotton. Transgenic Res 23(2):351-363. doi: 10.1007/s11248-013-9757-9

Alet AI, Sánchez DH, Cuevas JC, Marina M, Carrasco P, Altabella T, Tiburcio AF, Ruiz OA (2012) New insights into the role of spermine in Arabidopsis thaliana under long-term salt stress. Plant Sci 182:94-100

Alkio M, Tabuchi TM, Wang X, Colon-Carmona A (2005) Stress responses to polycyclic aromatic hydrocarbons in Arabidopsis include growth inhibition and hypersensitive response-like symptoms. J Exp Bot 56(421):29832994. doi: $10.1093 / \mathrm{jxb} / \mathrm{eri} 295$

Allakhverdiev SI, Sakamoto A, Nishiyama Y, Murata N (2000) Inactivation of photosystems I and II in response to osmotic stress in Synechococcus. Contribution of water channels. Plant Physiol 122(4):1201-1208

Al-Mailem DM, Sorkhoh NA, Marafie M, Al-Awadhi H, Eliyas M, Radwan SS (2010) Oil phytoremediation potential of hypersaline coasts of the Arabian Gulf using rhizosphere technology. Bioresour Technol 101:57865792

Al-Oudat M, Qadir M (2011) The halophytic flora of Syria. International Center for Agricultural Research in the Dry Areas, Aleppo, Syria

An R, Chen QJ, Chai MF, Lu PL, Su Z, Qin ZX, Chen J, Wang XC (2007) AtNHX8, a member of the monovalent cation: proton antiporter-1 family in Arabidopsis thaliana, encodes a putative $\mathrm{Li}^{+} / \mathrm{H}^{+}$antiporter. Plant J 49:718-728

Anderson JP, Badruzsaufari E, Schenk PM, Manners JM, Desmond OJ, Ehlert C, Maclean DJ, Ebert PR, Kazan K (2004) Antagonistic interaction between abscisic acid and jasmonate-ethylene signaling pathways modulates defense gene expression and disease resistance in Arabidopsis. Plant Cell 16(12):3460-3479

Aranjuelo I, Molero G, Erice G, Avice JC, Nogués S (2011) Plant physiology and proteomics reveals the leaf response to drought in alfalfa (Medicago sativa L.). J Exp Bot 62:111-123 
Arbona V, Flors V, Jacas J, García-Agustín P, Gómez-Cadenas A (2003) Enzymatic and non-enzymatic antioxidant responses of Carrizo citrange, a salt-sensitive citrus rootstock, to different levels of salinity. Plant Cell Physiol 44:388-394

Arbona V, Manzi M, de Ollas C, Gómez-Cadenas A (2013) Metabolomics as a tool to investigate abiotic stress tolerance in plants. Int J Mol Sci 14:4885-4911. doi:10.3390/ijms14034885

Arbona, V, Hossain Z, López-Climent MF, Pérez-Clemente RM, Gómez-Cadenas A (2008) Antioxidant enzymatic activity is linked to waterlogging stress tolerance in citrus. Physiol Plant 132:452-466

Barhoumi Z, Djebali W, Abdelly C, Chaïbi W, Smaoui A (2008) Ultrastructure of Aeluropus littoralis leaf salt glands under $\mathrm{NaCl}$ stress. Protoplasma 233(3-4):195-202. doi: 10.1007/s00709-008-0003-X

Ben Hamed K, Chibani F, Abdelly C, Magné C (2014) Growth, sodium uptake and antioxidant responses of coastal plants differing in their ecological status under increasing salinity. Biologia 69(2):193-201

Ben Hamed K, Ellouzi H, Talbi-Zribi O, Hessini K, Slama I, Ghnaya T, Munné Bosch S, Savouré A, Abdelly C (2013) Physiological response of halophytes to multiple stresses. Funct Plant Biol 40(9):883-896. doi:10.1071/FP13074

Ben Hassine A, Ghanem ME, Bouzid S, Lutts S (2009) Abscisic acid has contrasting effects on salt excretion and polyamine concentrations of an inland and a coastal population of the Mediterranean xero-halophyte species Atriplex halimus. Ann Bot 104(5):925-36. doi: 10.1093/aob/mcp174

Bitrián M, Zarza X, Altabella T, Tiburcio AF, Alcázar R (2012) Polyamines under abiotic stress: metabolic crossroads and hormonal cross talks in plants. Metabolites 2(3):516-528

Boriboonkaset T, Theerawitaya C, Yamada N, Pichakum A, Supaibulwatana K, Cha-Um S, Takabe T, Kirdmanee C (2013) Regulation of some carbohydrate metabolism-related genes, starch and soluble sugar contents, photosynthetic activities and yield attributes of two contrasting rice genotypes subjected to salt stress. Protoplasma 250(5):1157-1167. doi: 10.1007/s00709-013-0496-9

Bose J, Babourina O, Rengel Z (2011) Role of magnesium in alleviation of aluminium toxicity in plants. J Exp Bot 62:2251-2264. doi: 10.1093/jxb/erq456

Bose J, Rodrigo-Moreno A, Shabala S (2013) ROS homeostasis in halophytes in the context of salinity stress tolerance. J Exp Bot doi:10.1093/jxb/ert430 
Bowler C, Fluhr R (2000) The role of calcium and activated oxygens as signals for controlling cross-tolerance. Trends Plant Sci 5:241-246

Buchanan BB, Gruissem W, Jones RL (2000) Biochemistry and molecular biology of plants. Wiley-Blackwell, USA

Burken J, Schnoor J (1996) Phytoremediation: plant uptake of atrazine and role of root exudates. J Environ Eng 122(11):958-963

Cao J, Schneeberger K, Ossowski S, Günther T, Bender S, Fitz J, Koenig D, Lanz C, Stegle O, Lippert C, Wang X, Ott F, Müller J, Alonso-Blanco C, Borgwardt K, Schmi KJ, Weigel D (2011) Whole-genome sequencing of multiple Arabidopsis thaliana populations. Nat Genet 43:956-963. doi:10.1038/ng.911

Cardinale F, Meskiene I, Ouaked F, Hirt H (2002) Convergence and divergence of stress-induced mitogenactivated protein kinase signaling pathways at the level of two distinct mitogen-activated protein kinase kinases. Plant Cell (14):703-711

Casal JJ ( 2002) Environmental cues affecting development. Curr Opin Plant Biol 5(1):37-42

Cerniglia CE (1997) Fungal metabolism of polycyclic aromatic hydrocarbons: past, present and future applications in bioremediation. J Ind Microbiol Biotechnol 19(5-6):324-33

Chaturvedi AK, Mishra A, Tiwari V, Jha B (2012) Cloning and transcript analysis of type 2 metallothionein gene (SbMT-2) from extreme halophyte Salicornia brachiata and its heterologous expression in E. coli. Gene 499:280-287. doi: 10.1016/j.gene.2012.03.001

Chen J, Cheng T, Wang P, Liu W, Xiao J, Yang Y, Hu X, Jiang Z, Zhang S, Shi J (2012) Salinity-induced changes in protein expression in the halophytic plant Nitraria sphaerocarpa. J Proteomics (75):5226-5243. doi:10.1016/j.jprot.2012.06.006

Cidade LC, de Oliveira TM, Mendes AF, Macedo AF, Floh EI, Gesteira AS, Soares-Filho WS, Costa MG (2012) Ectopic expression of a fruit phytoene synthase from Citrus paradisi Macf. promotes abiotic stress tolerance in transgenic tobacco. Mol Biol Rep 39(12):10201-10209. doi: 10.1007/s11033-012-1895-2

Cobbett CS, Meagher RB (2002) Arabidopsis and the genetic potential for the phytoremediation of toxic elemental and organic pollutants. Arabidopsis Book.1:e0032. doi: 10.1199/tab.0032 
Colinet H, Larvor V, Laparie M, Renault D (2012) Exploring the plastic response to cold acclimation through metabolomics. Funct Ecol 26:711-722

Dassanayake M, Oh DH, Haas JS, Hernandez A, Hong H, Ali S, Yun DJ, Bressan RA, Zhu JK, Bohnert HJ, Cheeseman JM (2011) The genome of the extremophile crucifer Thellungiella parvula. Nat Genet 43(9):913918. doi: 10.1038/ng.889

D'Auria JC, Gershenzon J (2005) The secondary metabolism of Arabidopsis thaliana: growing like a weed. Curr Opin Plant Biol 8(3):308-316

de Campos MKF, de Carvalho K, de Souza FS, Marur CJ, Pereira LFP, Filho JCB, Vieira LGE (2011) Drought tolerance and antioxidant enzymatic activity in transgenic 'Swingle' citrumelo plants over-accumulating proline.

Environ Exp Bot. 72:242-250

Debez A, Ben Rejeb K, Ghars MA, Gandour M, Megdiche W, Ben Hamed K, Ben Amor N, Brown S C, Savouré A, Abdelly C (2013) Ecophysiological and genomic analysis of salt tolerance of Cakile maritima. Environ Exp Bot 92:64-72

Debez A, Saadaoui D, Slama I, Huchzermeyer B, Abdelly C (2010) Responses of Batis maritima plants challenged with up to two-fold seawater NaCl salinity. J Plant Nutr Soil Sci 173:291-299

Demidchik V, Cuin TA, Svistunenko D, Smith SJ, Miller AJ, Shabala S, Sokolik A, Yurin V (2010) Arabidopsis root $\mathrm{K}^{+}$-efflux conductance activated by hydroxyl radicals: single-channel properties, genetic basis and involvement in stress-induced cell death. J Cell Sci 123(9):1468-1479. doi: 10.1242/jcs.064352

Dooki AD, Mayer-Posner FJ, Askari H, Zaiee AA, Salekdeh GH (2006) Proteomic responses of rice young panicles to salinity. Proteomics 6(24):6498-6507

El-Bakatoushi R (2011) Identification and characterization of up-regulated genes in the halophyte Limoniastrum monopetalum (L.) Boiss grown under crude oil pollution. J Gen Engin Biotech 9(2):137-148. doi: 10.1016/j.jgeb.2011.10.001

Ellouzi H, Ben Hamed K, Asensi-Fabado MA, Müller M, Abdelly C, Munné-Bosch S (2013) Drought and cadmium may be as effective as salinity in conferring subsequent salt stress tolerance in Cakile maritima. Planta 237(5):1311-1323. doi: 10.1007/s00425-013-1847-7 
Ellouzi H, Hamed KB, Cela J, Munné-Bosch S, Abdelly C (2011) Early effects of salt stress on the physiological and oxidative status of Cakile maritima (halophyte) and Arabidopsis thaliana (glycophyte). Physiol Plant 142(2):128-143. doi: 10.1111/j.1399-3054.2011

Farhat N, Rabhi M, Krol M, Barhoumi Z, Ivanov A, Maccarthy A, Abdelly C, Smaoui A, Hüner NPA (2014) Starch and sugar accumulation in Sulla carnosa leaves upon $\mathrm{Mg}^{2+}$ starvation. Acta Physiol Plant 36(8):21572165. doi: 10.1007/s11738-014-1592-y

Farhat N, Ivanov A, Krol M, Rabhi M, Smaoui A, Abdelly C, Hüner NPA (2015) Preferential damaging effects of limited magnesium bioavailability on photosystem I in Sulla carnosa plants. Planta 241(5):1189-206. doi: $10.1007 / \mathrm{s} 00425-015-2248-\mathrm{x}$

Fismes J, Perrin-Ganier C, Empereur-Bissonnet P, Morel JL (2002) Soil-to-root transfer and translocation of polycyclic aromatic hydrocarbons by vegetables grown on industrial contaminated soils. J Environ Qual 31:1649-1656

Flowers TJ, Colmer TD (2008) Salinity tolerance in halophytes. New Phytol 179(4):945-963. doi: $10.1111 /$ j. $1469-8137.8$

Flowers TJ, Gaur PM, Gowda CL, Krishnamurthy L, Samineni S, Siddique KH, Turner NC, Vadez V, Varshney RK, Colmer TD (2010) Salt sensitivity in chickpea. Plant Cell Environ 33(4):490-509. doi: 10.1111/j.13653040.2009.02051.x

Fowler SG, Cook D, Thomashow MF (2005) Low temperature induction of Arabidopsis CBF1, 2, and 3 is gated by the circadian clock. Plant Physiol 137(3):961-968

Gechev TS, Dinakar C, Benina M, Toneva V, Bartels D (2012) Molecular mechanisms of desiccation tolerance in resurrection plants. Cell Mol Life Sci 69(19):3175-3186. doi: 10.1007/s00018-012-1088-0

Genoud T, Métraux JP (1999) Crosstalk in plant cell signaling: structure and function of the genetic network. Trends Plant Sci 4(12):503-507

Ghnaya T, Nouairi I, Slama I, Messedi D, Grignon C, Abdelly C, Ghorbel MH (2005) Cadmium effects on growth and mineral nutrition of two halophytes: Sesuvium portulacastrum and Mesembryanthemum crystallinum. J Plant Physiol 162(10):1133-1140 
Ghnaya T, Slama I, Messedi D, Grignon C, Ghorbel MH, Abdelly C (2007) Effects of $\mathrm{Cd}^{2+}$ on $\mathrm{K}^{+}$, $\mathrm{Ca}^{2+}$ and N uptake in two halophytes Sesuvium portulacastrum and Mesembryanthemum crystallinum: consequences on growth. Chemosphere 67(1):72-79

Gil R, Lull C, Boscaiu M, Bautista I, A Lidon A, Vicente O (2011) Soluble carbohydrates as osmolytes in several halophytes from a Mediterranean salt marsh. Not Bot Horti Agrobo 39(2):9-17

Gleick PH, Christian-Smith J, Cooley H (2011) Water-use efficiency and productivity: rethinking the basin approach. Water Intern. 36:784-798

Glenn EP, Nelson SG, Ambrose B, Martinez R, Soliz D, Pabendinskas V, Hultine K (2012) Comparison of salinity tolerance of three Atriplex spp. in well-watered and drying soils. Environ Exp Bot 83:62-72

Gulzar S, Khan M A, Ungar I A (2003) Salt tolerance of a coastal salt marsh grass. Comm Soil Sci Plant Anal 34:2595-2605. doi: 10.1081/CSS-120024787

Hafsi C, Lakhdhar A, Rabhi M, Debez A, Abdelly C, Ouerghi Z (2007) Interactive effects of salinity and potassium availability on growth, water status, and ionic composition of Hordeum maritimum. J Plant Nutr Soil Sci 170(4): 469-473

Hossain MA, Piyatida P, Teixeira da Silva JA and Fujita M (2012) Molecular mechanism of heavy metal toxicity and tolerance in plants: central role of glutathione in detoxification of reactive oxygen species and methylglyoxal and in heavy metal chelation. J Bot. doi:10.1155/2012/872875

Howes Keiffer C, Ungar IA (2002) Germination and establishment of halophytes on brine-affected soils. J Appl Ecol 39:402-415

Iseki K, Homma K, Endo T, Shiraiwa T (2013) Genotypic diversity of cross-tolerance to oxidative and drought stresses in rice seedlings evaluated by the maximum quantum yield of photosystem II and membrane stability. Plant Prod Sci 16(4): 295-304

Jithesh MN, Prashanth SR, Sivaprakash KR, Parida AK (2006) Antioxidative response mechanisms in halophytes: their role in stress defence. J Genet 85(3):237-254

Kanaly RA, Harayama S (2000) Biodegradation of high-molecular-weight polycyclic aromatic hydrocarbons by bacteria. J Bacteriol 182(8):2059-2067 
Kaplan F, Kopka J, Haskell DW, Zhao W, Schiller KC, Gatzke N, Sung DY, Guy CL (2004) Exploring the temperature-stress metabolome of Arabidopsis. Plant Physiol 136(4):4159-4168

Karan R, Subudhi PK (2012) A stress inducible SUMO conjugating enzyme gene (SaSce9) from a grass halophyte Spartina alterniflora enhances salinity and drought stress tolerance in Arabidopsis. BMC Plant Biol 12:187. doi: 10.1186/1471-2229-12-187

Kavitha K, Venkataraman G, Parida A (2008) An oxidative and salinity stress induced peroxisomal ascorbate peroxidase from Avicennia marina: molecular and functional characterization. Plant Physiol Biochem 46(89):794-804. doi: 10.1016/j.plaphy.2008

Kipopoulou AM, Manoli E, Samara C (1999) Bioconcentration of polycyclic aromatic hydrocarbons in vegetables grown in an industrial area. Environ Pollut 106(3):369-80

Koch K (2004) Sucrose metabolism: regulatory mechanisms and pivotal roles in sugar sensing and plant development. Curr Opin Plant Biol 7(3):235-46

Komatsu S, Konishi H, Hashimoto M (2007) The proteomics of plant cell membranes. J Exp Bot 58:103-112

Komives T, Gullner G (2005) Phase I xenobiotic metabolic systems in plants. Z Naturforsch C. 60(3-4):179-185

Kondrashov FA (2012) Gene duplication as a mechanism of genomic adaptation to a changing environment. Proc Biol Sci 279(1749):5048-5057. doi: 10.1098/rspb.2012.1108

Kosová K, Vítámvás P, Planchon S, Renaut J, Vanková R, Prásil IT (2013) Proteome analysis of cold response in spring and winter wheat (Triticum aestivum) crowns reveals similarities in stress adaptation and differences in regulatory processes between the growth habits. J Proteome Res 12(11):4830-4845. doi: 10.1021/pr400600g

Kremer P, Van Andel J (1995) Evolutionary aspects of life forms in angiosperm families. Act Bot Neerl 44(4):469-479

Labidi N, Ammari M, Messedi D, Benzerti M, Snoussi S, Abdelly C (2010) Salt excretion in Suaeda fruticosa. Acta Biol Hung 61(3):299-312

Leach CR, Mayo O, Bürger R (1990) Quantitatively determined self-incompatibility: 2. Outcrossing in Borago officinaux. Theor Appl Genet 79(3):427-430. doi: 10.1007/BF01186090 
Li D, Han X, Zuo J, Xie L, He R, Gao J, Chang L, Yuan L, Cao M (2011) Construction of rice site-specific chloroplast transformation vector and transient expression of EGFP gene in Dunaliella salina. J Biomed Nanotechnol 7(6):801-806

Liu H, Weisman D, Ye Y, Cui B, Huang Y, Colon-Carmona A, Wang Z (2009) An oxidative stress response to polycyclic aromatic hydrocarbon exposure is rapid and complex in Arabidopsis thaliana. Plant Sci 176:375-382. doi: 10.1016/j.plantsci.2008.12.002

Lu Z, Chang T, Li X, Xu J, Li H, Chen W, Feng D, Xiao G, Zhu Z (2003) The expression of tga1 a gene from tobacco affects the expression of exogenous gene in transgenic plant. Sci China C Life Sci 46(2):141-152. doi: $10.1360 / 03$ yc9016

Mahajan S, Tuteja N (2005) Cold, salinity and drought stresses: an overview. Arch Biochem Biophys 444(2):139-158

Manousaki E, Kalogerakis N (2011) Halophytes an emerging trend in phytoremediation. Int J Phytoremed 13(10):959-969

Martin-Tanguy J (1997) Conjugated polyamines and reproductive development: Biochimical, molecular and physiological approaches. Physiol Plant 100:675-688

Masciandaro G, Di Biase A, Macci C, Peruzzi E, Iannelli R, Doni S (2014) Phytoremediation of dredged marine sediment: monitoring of chemical and biochemical processes contributing to sediment reclamation. J Environ Manage 134:166-174. doi: 10.1016/j.jenvman.2013

Mendoza-Cózatl DG, Zhai Z, Jobe TO, Akmakjian GZ, Song WY, Limbo O, Russell MR, Kozlovskyy VI, Martinoia E, Vatamaniuk OK, Russell P, Schroeder JI (2010) Tonoplast-localized Abc2 transporter mediates phytochelatin accumulation in vacuoles and confers cadmium tolerance. J Biol Chem (52):40416-26. doi:10.1074/jbc.M110.155408

Meudec A, Dussauze J, Deslandes E, Poupart N (2005) Uptake of four PAHs occurring into aerial plant tissue artificially exposed to heavy fuel oil in Salicornia. IOSC Proceedings 2005(1):797-800. doi: 10.7901/2169$3358-2005-1-797$

Mittler R (2002) Oxidative stress, antioxidants and stress tolerance. Trends Plant Sci 7:405-410

Mittler R (2006) Abiotic stress, the field environment and stress combination. Trends Plant Sci 11(1):15-19 
Mittler R, Vanderauwera S, Gollery M, Van Breusegem F (2004) Reactive oxygen gene network of plants. Trends Plant Sci 9(10):490-498

Munns R (2002) Comparative physiology of salt and water stress. Plant Cell Environ 25(2):239-250

Munns R, Tester M (2008) Mechanisms of salinity tolerance. Annu Rev Plant Biol 59:651-681. doi: 10.1146/annurev.arplant.59.032607.092911

Nagaoka S, Takano T (2003) Salt tolerance-related protein STO binds to a Myb transcription factor homologue and confers salt tolerance in Arabidopsis. J Exp Bot 54(391):2231-2237

Nawaz I, Iqbal M, Hakvoort HWJ, Bliek M, de Boer B, Schat H (2014) Expression levels and promoter activities of candidate salt tolerance genes in halophytic and glycophytic Brassicaceae. Environ Exp Bot 99:59-66. doi: 10.1016/j.envexpbot.2013.10.006

O’Leary J, Glenn E (1994) Global distribution and potential for halophytes. In Squire VR and Ayoub A (ed) Halophytes as a resources for livestock and for rehabilitation of degraded Land. Kluwer Academic, Netherlands, pp $7-17$

Oliver MJ, Jain R, Balbuena TS, Agrawal G, Gasulla F, Thelen JJ (2011) Proteome analysis of leaves of the desiccation-tolerant grass, Sporobolus stapfianus, in response to dehydration. Phytochemistry 72(10):12731284. doi: 10.1016/j.phytochem.2010.10.020

Oztürk ZN, Talamé V, Deyholos M, Michalowski CB, Galbraith DW, Gozukirmizi N, Tuberosa R, Bohnert HJ (2002) Monitoring large-scale changes in transcript abundance in drought-and salt-stressed barley. Plant Mol Biol 48:551-573

Parida AK, Jha B (2013) Physiological and biochemical responses reveal the drought tolerance efficacy of the halophyte Salicornia brachiata. J Plant Growth Regul 32(2):342-352

Parida A, Das AB, Das P (2002) NaCl stress causes changes in photosynthetic pigments, proteins and other metabolic components in the leaves of a true mangrove, Bruguiera parviflora, in hydroponic cultures. J Plant Biol 45:28-36

Rabhi M, Ferchichi S, Jouini J, Hamrouni MH, Koyro HW, Ranieri A, Abdelly C, Smaoui A (2010a) Phytodesalination of a salt-affected soil with the halophyte Sesuvium portulacastrum L. to arrange in advance the requirements for the successful growth of a glycophytic crop. Bioresour Technol 101:6822-6828 
Rabhi M, Giuntini D, Remorini D, Castagna A, Baldan B, Smaoui A, Abdelly C, Ranieri A (2010b) Sesuvium portulacastrum maintains adequate gas exchange, pigment composition, and thylakoid proteins under moderate and high salinity. J Plant Physiol 167:1336-1341

Rabhi M, Hajji S, Karray-Bouraoui N, Giuntini D, Castagna A, Smaoui A, Ranieri A, Adelly C (2010c) Nutrient uptake and management under saline conditions in the xerohalophyte: Tecticornia indica (Willd.) subsp. indica. Acta Biol Hung 61(4):486-497. doi: 10.1556/ABiol.61.2010.4.11

Rabhi M, Karray-Bouraoui N, Medini R, Attia H, Athar H, Lachaal M, Abdelly C, Smaoui A (2010d) Seasonal variations in the capacities of phytodesalination of a salt-affected soil in two perennial halophytes in their natural biotope. J Biol Res 14:181-189

Ribeiro H, Mucha AP, Almeida CM, Bordalo AA (2014) Potential of phytoremediation for the removal of petroleum hydrocarbons in contaminated salt marsh sediments. J Environ Manage 137:10-15. doi: 10.1016/j.jenvman.2014.01.047

Rolland F, Baena-Gonzalez E, Sheen J (2006) Sugar sensing and signaling in plants: conserved and novel mechanisms. Annu Rev Plant Biol 57:675-709

Rouached A, Slama I, Zorrig W, Jdey A, Cukier C Rabhi M, Talbi O, Limami A M, Abdelly C (2013) Differential performance of tow forage species, Medicago truncatula and Sulla carnosa, under water-deficit stress and recovery. Crop Past Sci 64(3):254-264. doi: 10.1071/CP13049

Ruan YL (2014) Sucrose metabolism: gateway to diverse carbon use and sugar signaling. Annu Rev Plant Biol 65:33-67. doi: 10.1146/annurev-arplant-050213-040251

Saibo NJ, Lourenço T, Oliveira MM (2009) Transcription factors and regulation of photosynthetic and related metabolism under environmental stresses. Ann Bot (4):609-23. doi: 10.1093/aob/mcn227

Salt DE, Smith RD, Raskin I (1998) Phytoremediation. Annu Rev Plant Physiol Plant Mol Biol 49:643-668. doi: 10.1146/annurev.arplant.49.1.643

Sandermann HJr (1992) Plant metabolism of xenobiotics. Trends Biochem Sci 17(2):82-84

Sandermann HJr (1994) Higher plant metabolism of xenobiotics: the "green liver" concept. Pharmacogenetics 4(5):225-241 
Sargeant M, Sale P, Tang C (2006) Salt priming improves establishment of Distichlis spicata under saline conditions. Aust J of Agric Res 57(12):1259-1265. doi: 10.1071/AR06103

Shabala S (2009) Salinity and programmed cell death: unravelling mechanisms for ion specific signaling. J Exp Bot 60(3):709-712. doi: 10.1093/jxb/erp013

Shabala S, Cuin TA, Prismall L, Nemchinov LG (2007) Expression of animal CED-9 anti-apoptotic gene in tobacco modifies plasma membrane ion fluxes in response to salinity and oxidative stress. Planta 227(1):189-97

Shaikh F, Gul B, Li WQ, Liu XJ, Khan MA (2007) Effect of calcium and light on the germination of Urochondra setulosa under different salts. J Zhejiang Univ Sci B 8(1):20-26

Sharp RE, Poroyko V, Hejlek LG, Spollen WG, Springer GK, Bohnert HJ, Nguyen HT (2004) Root growth maintenance during water deficits: physiology to functional genomics. J Exp Bot 55:2343-2351

Shiri M, Rabhi M, El Amrani A, Abdelly C (2015) The halophyte Cakile maritima reduces phenanthrene phytotoxicity. Int J Phytoremediation (In press).

Shiri M, Rabhi M, Abdelly C, El Amrani A (2014) The halophytic model plant Thellungiella salsuginea exhibited increased tolerance to phenanthrene-induced stress in comparison with the glycophitic one Arabidopsis thaliana: Application for phytoremediation. Ecol Eng 74:125-134

Simonich SL, Hites RA (1994) Vegetation-atmosphere partitioning of polycyclic aromatic hydrocarbons. Environ Sci Technol 28(5):939-943. doi: 10.1021/es00054a028

Singh N, Mishra A, Jha B (2013) Over-expression of the peroxisomal ascorbate peroxidase (SbpAPX) gene cloned from halophyte Salicornia brachiate confers salt and drought stress tolerance in transgenic tobacco. Mar Biotechnol (16)321-332. doi: 10.1007/s10126-013-9548-6

Slama I, Ghnaya T, Messedi D, Hessini K, Labidi N, Savoure A, Abdelly C (2007) Effect of sodium chloride on the response of the halophyte species Sesuvium portulacastrum grown in mannitol-induced water stress. J Plant Res 120(2):291-299

Smaoui A, Barhoumi Z, Rabhi M, Abdelly C (2010) Localization of potential ion transport pathways in vesicular trichome cells of Atriplex halimus L. Protoplasma 248(2):363-72. doi: 10.1007/s00709-010-0179-8

Snowden KC, Richards KD, Gardner RC (1995) Aluminum-induced genes: induction by toxic metals, low calcium, and wounding and pattern of expression in root tips. Plant Physiol 107(2):341-348 
Sobrado M (2001) Effect of drought on leaf gland secretion of the mangrove Avicennia germinans L. Trees 16(1):1-4. doi: 10.1007/s004680100122

Sobrado MA, Greaves ED (2000) Leaf secretion composition of the mangrove species Avicennia germinans (L.) in relation to salinity: a case study by using total-reflection X-ray fluorescence analysis. Plant Sci 159(1):1-5

Sohn KH, Lee SC, Jung HW, Hong JK, Hwang BK (2006) Expression and functional roles of the pepper pathogen-induced transcription factor RAV1 in bacterial disease resistance, and drought and salt stress tolerance. Plant Mol Biol 61:897-915

Szabados L, Savouré A (2010) Proline: a multifunctional amino acid. Trends Plant Sci 15:89-97

Talbi-Zribi O, Labidi N, Slama I, Debez A, Ksouri R, Rabhi M, Smaoui A, Abdelly C (2012) Alleviation of phosphorus deficiency stress by moderate salinity in the halophyte Hordeum maritimum L. Plant Growth Regul 66(1):75-85. doi: 10.1007/s10725-011-9631-9

Tissut M, Raveton M, Ravanel P (2006) Ecoremediation. Cooperation between plants and soil microorganisms, molecular aspects and limits. In Twardowska I, Allen HE, Haggblom MM, Stefaniak S (ed) Viable methods of soil and water pollution monitoring, protection and remediation pp 489-504

Tommasini R, Vogt E, Fromenteau M, Hoertensteiner S, Matile P, Amrhein N, Martinoia E (1998) An ABC-transporter of Arabidopsis thaliana has both glutathione-conjugate and chlorophyll catabolite transport activity. Plant J 13:773-780

Udawat P, Mishra A, Jha B (2014) Heterologous expression of an uncharacterized universal stress protein gene (SbUSP) from the extreme halophyte, Salicornia brachiata, which confers salt and osmotic tolerance to E. coli. Gene 536(1):163-70. doi: 10.1016/j.gene.2013.11.020

Van Poecke RM, Posthumus MA, Dicke M (2001) Herbivore-induced volatile production by Arabidopsis thaliana leads to attraction of the parasitoid Cotesia rubecula: chemical, behavioral, and gene-expression analysis. J Chem Ecol 27(10):1911-1928

Vanhove AC, Vermaelen W, Panis B, Swennen R, Carpentier SC (2012) Screening the banana biodiversity for drought tolerance: can an in vitro growth model and proteomics be used as a tool to discover tolerant varieties and understand homeostasis. Front Plant Sci 3:176. doi: 10.3389/fpls.2012.00176 Vaziri A, Motamed N, Naghavi MR, Yazdani B, Niknam V (2011) Physiological and biochemical responses of Aeluropus lagopoides and Aeluropus littoralis to drought stress. OAJMAP 2:5-14 
Weber DJ (2009) Adaptive mechanisms of halophytes in desert regions. In Ashraf M, Oztürk M, Athar HR (ed) Salinity and water stress, Springer-Verlag, pp 179-186

Wenzel WW, Adriano DC, Salt D and Smith R (1999) Phytoremediation: a plant-microbe-based remediation system. American Society of Agronomy, Crop Science Society of America, Soil Science Society of America, Madison, WI, USA.

Wild E, Dent J, Barber JL, Thomas GO, Jones KC (2004) A novel analytical approach for visualizing and tracking organic chemicals in plants. Environ Sci Technol 38:4195-4199

Witt S, Galicia L, Lisec J, Cairns J, Tiessen A, Araus JL, Palacios-Rojas N, Fernie AR (2012) Metabolic and phenotypic responses of greenhouse-grown maize hybrids to experimentally controlled drought stress. Mol Plant 5(2):401-417. doi: $10.1093 / \mathrm{mp} / \mathrm{ssr} 102$

Wu HJ, Zhang Z, Jun-Yi Wang JY, Oh DH, Dassanayake M, Liu B, Huang Q, Sun HX, Xia R, Wu Y, Wang YN, Yang Z, Liu Y, Zhang W, Zhang H, Chu J, Yan C, Fang S, Zhang J, Wang Y, Zhang F, Wang G, Lee SY, Cheeseman JM, Yang B, Li B, Min J, Yang L, Wang J, Chu C, Chen SY, Bohnert HJ, Zhu JK, Wang XJ, Xie Q (2012) Insights into salt tolerance from the genome of Thellungiella salsuginea. Proc Natl Acad Sci USA 109(30):12219-12224. doi: 10.1073/pnas.1209954109

Wyn Jones G, Gorham J (2002) Intra-and intercellular compartmentation of ions. In Läuchli A, Lüttge U (ed) Salinity-Environment-Plants-Molecules. Kluwer Academic Publishers, Dordrecht, The Netherlands, pp 159-180 Xiong L, Yang Y (2003) Disease resistance and abiotic stress tolerance in rice are inversely modulated by an abscisic acid-inducible mitogen-activated protein kinase. Plant Cell 15(3):745-759

Yoshiba Y, Yamaguchi-Shinozaki K, Shinozaki K, Harada Y (1995) Characterization of a cDNA clone encoding $23 \mathrm{kDa}$ polypeptide of the oxygen-evolving complex of photosystem II in rice. Plant Cell Physiol 36(8):16771682

Yousfi S, Rabhi M, Hessini K, Abdelly C, Gharsalli M (2010) Differences in efficient metabolite management and nutrient metabolic regulation between wild and cultivated barley grown at high salinity. Plant Biol 12(4):650-658. doi: 10.1111/j.1438-8677.2009.00265.x

Yu J, Chen S, Wang T, Sun G, Dai S (2013) Comparative proteomic analysis of Puccinellia tenuiflora leaves under $\mathrm{Na}_{2} \mathrm{CO}_{3}$ stress. Int J Mol Sci 14(1):1740-1762. doi: 10.3390/ijms14011740 
Yu J, Chen S, Zhao Q, Wang T, Yang C, Diaz C, Sun G, Dai S (2011) Physiological and proteomic analysis of salinity tolerance in Puccinellia tenuiflora. J Proteome Res 10(9):3852-3870. doi: 10.1021/pr101102p

Zaier H, Ghnaya T, Lakhdar A, Baioui R, Ghabriche R, Mnasri M, Sghair S, Lutts S, Abdelly C (2010). Comparative study of Pb-phytoextraction potential in Sesuvium portulacastrum and Brassica juncea: tolerance and accumulation. J Hazard Mater 183(1-3):609-615. doi: 10.1016/j.jhazmat.2010.07.068

Zepeda-Jazo I, Velarde-Buendía AM, Enríquez-Figueroa R, Bose J, Shabala S, Muñiz-Murguía J, Pottosin II (2011) Polyamines interact with hydroxyl radicals in activating $\mathrm{Ca}^{(2+)}$ and $\mathrm{K}^{(+)}$transport across the root epidermal plasma membranes. Plant Physiol 157(4):2167-2180. doi: 10.1104/pp.111.179671

Zhan J, Li W, He HY, Li CZ, He LF (2013) Mitochondrial alterations during Al-induced PCD in peanut root tips. Plant Physiol Biochem 75:105-113. doi: 10.1016/j.plaphy.2013.12.010

Zhan M, Cao CG, Jiang Y, Wang JP, Yue LX, Cai ML (2010) Dynamics of active organic carbon in a paddy soil under different rice farming modes. Ying Yong Sheng Tai Xue Bao 21(8):2010-2016

Zhu JK (2002) Salt and drought stress signal transduction in plants. Annu Rev Plant Biol 53:247-273. doi: 10.1146/annurev.arplant.53.091401.143329 